\title{
ANALISIS PERILAKU INDIKATOR DEBT MARKET
}

\section{Peter Jacobs, Arlyana Abubakar, Tora Erita Siallagan ${ }^{1}$}

\begin{abstract}
This paper analyze the debt market, focusing on the behavior of soverign yield and Credit Default Swap (CDS). We build several empirical models to test the factors determine these two indicators and apply them using the Indonesian and peers data. The result confirm the significance impact of foreign reserves and VIX index on the bond yield in Indonesia and its peers country. On the composite sovereign bond, the result shows that the real effective exchange rate (REER) and the debt service ratio (DSR) significantly affect the yield, while on the corporate bond yield, the significant explanatory variables are return on equity (ROE), inflation, the current ratio (CR) and net profit margin (NPM). However, there is an anomaly where the impact of the last two variables (CR and NPM) are contrary to the theory.
\end{abstract}

Keyword: Sovereign, bond, yield, debt market, risk, corporate fundamentals.

JEL Classification: H63, G31

1 Peter Jacobs adalah kepala bagian Analisis Pinjaman Luar Negeri dan Hubungan Investor - Direktorat Internasional Bank Indonesia (pjacobs@bi.go.id), Arlyana Abubakar adalah Analis Ekonomi Madya (arlyana@bi.go.id) dan Tora Erita Siallagan adalah Analis Ekonomi Muda Senior (toraerita@yahoo.com), pada bagian yang sama. 


\section{PENDAHULUAN}

Perkembangan pasar keuangan global yang sangat cepat dan semakin terintegrasi tidak mungkin dapat dibendung. Perubahan yang terjadipun direspon cepat oleh indikator pasar keuangan. Perkembangan pasar keuangan yang semakin pesat dan semakin terintegrasi memberikan dampak positif dan negatif bagi perkembangan pasar keuangan dalam negeri. Mudahnya efek penularan krisis merupakan salah satu dampak negatifnya. Berbagai isu dibelahan dunia, bahkan yang tidak terkait langsung dengan kondisi suatu negara atau korporasi, direspon secara cepat oleh pergerakan indikator pasar keuangan, khususnya debt market. Lalu bagi Bank Indonesia, seberapa penting untuk selalu mencermati perkembangan indikator pasar keuangan, khususnya debt market?

Indikator debt market merefleksikan apresiasi pasar terhadap risiko memberikan pinjaman luar negeri, khususnya dalam bentuk penerbitan global bond baik di primary maupun secondary market. Hal ini secara langsung mempengaruhi bagaimana pergerakan supply demand valas yang berasal dari pinjaman luar negeri dan portfolio investment.

Dengan menganut rejim nilai tukar bebas mengambang (dan inflasi sebagai sasaran akhir) dapat dicapai independensi kebijakan moneter dan integrasi pasar keuangan, maka Bank Indonesia diyakini tidak dapat secara simultan mencapai sasaran stabilitas nilai tukar (exchange

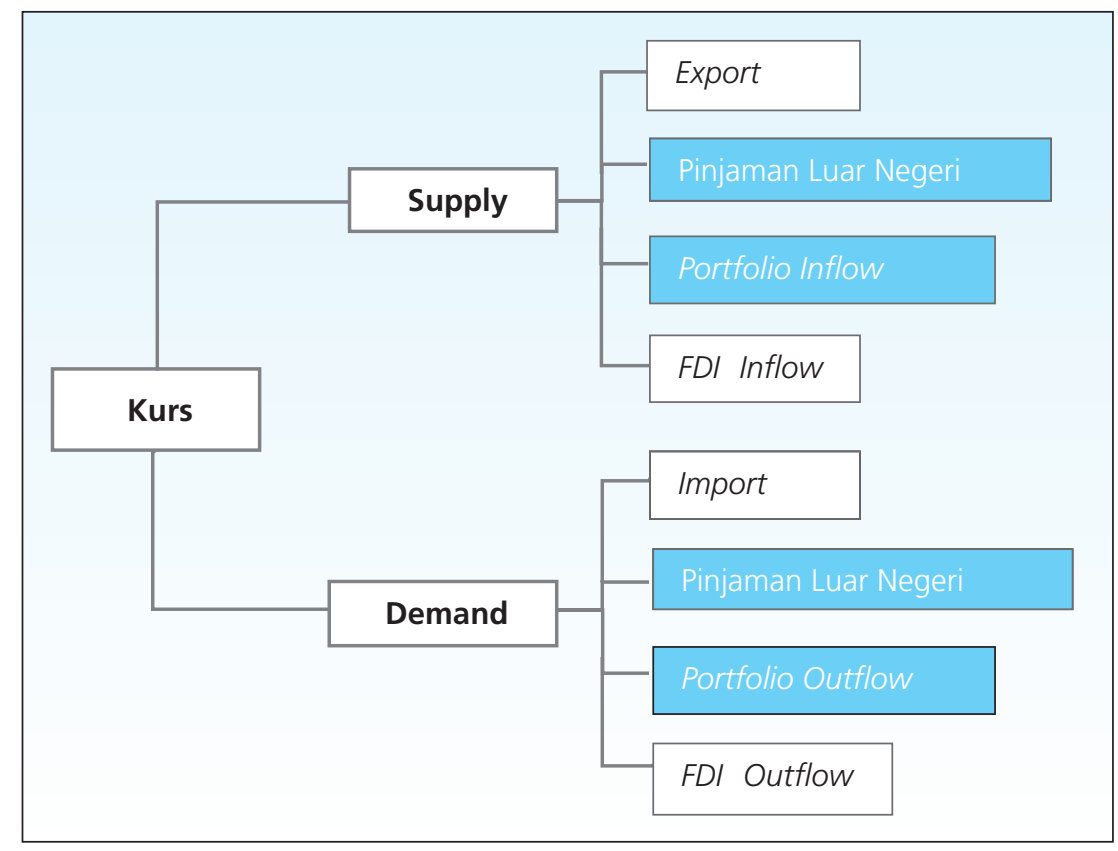

Bagan 1. Struktur Supply-Demand Valas 
rate stability) yang dikenal dengan Impossible Trinity Theory. Nilai tukar akan berfluktuasi ditentukan oleh kekuatan supply demand valas dipasar. Namun demikian, supply demand devisa tetap perlu dikelola agar nilai tukar rupiah bergerak sesuai dengan kondisi fundamental ekonomi dan tidak berfluktuasi berlebihan. Fluktuasi nilai tukar yang berlebihan menggangu kestabilan makro dan kesinambungan pertumbuhan ekonomi dalam jangka panjang. Sementara itu, struktur supply demand valas sendiri pada dasarnya terdiri dari 4 aliran, yaitu: (1) ExportImport; (2) Pinjaman Luar Negeri; (3) Portfolio Investment; dan (4) Foreign Direct Investment (FDI). Oleh karena itu, sangatlah penting bagi Bank Indonesia untuk mencermati dan meneliti pergerakan (behaviour) dari berbagai indikator debt market, khususnya faktor-faktor yang secara fundamental mempengaruhi pergerakan indikator debt market.

Indikator debt market yang banyak dipakai adalah yield global bond dan belakangan yang banyak digunakan adalah CDS. Sebagai contoh, pada 26 Februari 2009, pemerintah Indonesia melakukan penawaran Global Medium Term Notes (GMTN) senilai total USD 3 miliar dengan rating Ba3 (Moody's)/BB- (S\&P) dan BB (Fitch) yang terdiri dari 2 bagian (tranches). Tranche 1 sebesar USD 1 miliar, bertenor 5 tahun, diterbitkan dengan kupon $10.375 \%$, yield 10.5\% (8,474\% diatas UST dengan tenor sama) dan pada posisi harga diskon 99.455\%; sedangkan Tranche 2 sebesar USD 2 miliar, tenor 10 tahun, kupon $11.625 \%$, yield $11.75 \%$ (8,759\% diatas UST dengan tenor sama) dan price $99.276 \%$. Notes tersebut merupakan surat utang terbesar di Asia dan surat utang terbesar yang pernah ditawarkan oleh pemerintah Indonesia.

Jika dibandingkan dengan penerbitan surat utang negara peers (memiliki rating hampir sama dengan Indonesia), yaitu pemerintah Philipine pada Januari 2009, Turkey pada September
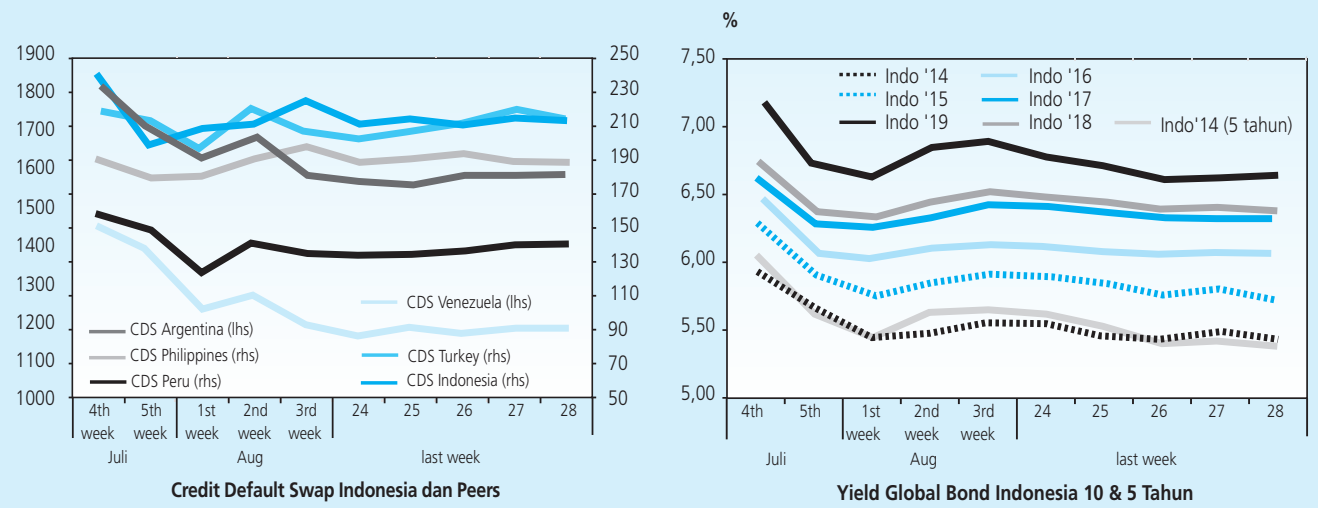

Grafik 1. Obligasi Pemerintah 10 tahun dan CDS Indonesia dan Peers

Sumber : Bloomberg 2009 
2008 dan Brazil pada awal 2009, kupon dan yield penerbitan GMTN pemerintah Indonesia tersebut termasuk mahal. Namun harga yang mahal ini tidak dapat dihindari karena pada saat penerbitan GMTN, yield global bond Indo' 18 (10 tahun) berada pada kisaran 10\% sd 11\% dan CDS Indonesia berada pada kisaran 640 sd. 661 bps. Peningkatan yield global bond Indo'18 (10 tahun) dan CDS terjadi secara signifikan pada awal bulan menjelang penerbitan GMTN dan mencapai puncaknya pada saat pricing dilakukan. Peningkatan indikator yield global bond dan CDS dari waktu ke waktu, secara sigifikan mempengaruhi cost of fund penerbitan global Indonesia, diharapkan demikian pula sebaliknya.

\begin{tabular}{|c|c|c|c|c|c|c|c|c|}
\hline Tahun & Issuance date & $\begin{array}{c}\text { Yield } \\
\text { at Issuance }\end{array}$ & 2003 & 2004 & 2005 & 2006 & 2007 & 2008 \\
\hline $\mathrm{INDO}^{\prime} 17($ coupon $=7.5 \%)$ & 3-Feb-06 & $7.00 \%$ & - & - & - & 6.78 & 6.22 & 7.92 \\
\hline INDO'14 (coupon = 6.75\%) & March 3, 2004 & $6.85 \%$ & - & 7.50 & 6.85 & 6.62 & 6.08 & 7.46 \\
\hline INDO'15 (coupon = $7.25 \%)$ & April113, 2005 & $7.38 \%$ & - & - & 7.27 & 6.69 & 6.15 & 7.70 \\
\hline INDO'16 (coupon = 7.5\%) & October[5, 2005 & $7.63 \%$ & - & - & 7.33 & 6.76 & 6.21 & 7.80 \\
\hline INDO'35 $($ coupon $=8.5 \%)$ & October[5, 2005 & $8.63 \%$ & - & - & 8.23 & 7.36 & 6.89 & 8.58 \\
\hline INDO'37 (coupon = 6.75\%) & 7-Feb-07 & $6.75 \%$ & - & - & - & - & 6.89 & 8.44 \\
\hline INDO'38 (coupon = 6.75\%) & January 17, 2008 & $7.75 \%$ & - & - & - & - & - & 8.63 \\
\hline INDO'18 (coupon = 6.875\%) & January 17, 2008 & $6.95 \%$ & - & - & - & - & - & 7.96 \\
\hline INDO'140504 (coupon = 10.3750\%) & 4-Mar-09 & $10.50 \%$ & - & - & - & - & - & - \\
\hline INDO'190304 (coupon=11.625\%) & 4-Mar-09 & $11.75 \%$ & - & - & - & - & - & - \\
\hline
\end{tabular}

Sumber: Bloomberg 2009

Lebih lanjut, pada 16 April 2009, pemerintah Indonesia telah menetapkan harga penawaran SBSN (Surat Berharga Syariah Negara) atau Sukuk Negara sebesar USD 650 juta. Sukuk tersebut dijual dengan harga nominal 100\% dengan tingkat imbalan tetap sebesar 8,8\% per tahun, tenor 5 tahun dengan tanggal penerbitan 23 April 2009. Penerbitan Sukuk Negara valas tersebut merupakan penerbitan perdana bagi Pemerintah di pasar internasional sekaligus penerbitan straight sukuk terbesar dalam denominasi USD di luar negara-negara GCC dan merupakan benchmark pertama sukuk dalam denominasi USD di Asia sejak tahun 2007. Harga Sukuk Negara yang relatif lebih rendah bila dibandingkan dengan penerbitan sebelumnya, selain disinyalir karena struktur transaksi yang lebih secure, tidak terlepas dari kondisi reference yield global bond dan CDS Indonesia yang cenderung menurun.

Beberapa penelitian indikator debt market telah dilakukan, diantaranya meneliti hubungan antara CDS korporasi dan yield obligasi (Houweling et al 2001)² dan Hull et al (2003), perbedaan CDS korporasi dan yield spread hanya timbul pada jangka pendek namun akan mencapai harga

2 Howeling, P. and T. Vorst (2001) "An Empirical Comparison of Default Swap Pricing Models", mimeo, Rabobank, December 2001 
ekuilibrium dalam jangka panjang (Zhu 2006). Penelitian lain dengan menerapkan Vector Error Correction Model (VECM) ditemukan bahwa sovereign CDS dan sovereign bond market mempunyai perbedaan harga yang signifikan. Namun sangat jarang kajian yang meneliti CDS sebagai indikator sovereign risk (Cossin and Jung 2005).

Disamping individual yield spread, terdapat juga yield compositeyang merupakan indikator yang dibaca pasar sebagai indikasi performa debt market negara atau kawasan tertentu. Yield spread composite seperti EMBI, EMBI Global, EMBI+ dan CEMBIC menggambarkan yield beberapa negara emerging market (sovereign bond untuk tiga pertama dan corporate bond untuk yang terakhir). Spread composite yang diterbitkan oleh J.P Morgan tersebut menggambarkan perbedaan antara yield obligasi sovereign bonds emerging market dengan yield obligasi yang dianggap 'risk free' (T-bill atau T-bond yang diterbitkan oleh pemerintah AS atau negara maju lainnya).

Penelitian ini berbeda dari penelitian-penelitian sebelumnya karena penelitian ini secara khusus meneliti behaviour dari beberapa indikator debt market yang umum dijadikan acuan oleh pelaku dan analis debt market internasional pada pasar obligasi pemerintah dan swasta Indonesia. Namun untuk indikator tertentu, dalam rangka mempertajam analisis, juga dibandingkan dengan negara-negara peers antara lain dikawasan Asia (Philippine dan Turkey), Latam (Brazil) dan Afrika Selatan. Oleh karena itu, memperhitungkan kemungkinan keunikan kondisi negara maka setidaknya hasil penelitian ini dapat menggambarkan kondisi Indonesia walaupun tidak menutup kemungkinan dapat diterapkan untuk negara lainnya, terutama untuk negara dengan karakteristik yang hampir sama dengan Indonesia.

Secara umum, penelitian difokuskan pada indikator debt market yang sering digunakan sebagai cerminan apresiasi pasar dalam memberikan pinjaman luar negeri pemerintah dan swasta, khususnya dalam bentuk penerbitan global bond baik di primary maupun secondary market, yaitu: yield sovereign global bond, yield corporate global bond, composite yields dan CDS.

Secara khusus, paper ini bertujuan untuk menganalisis dan memformulasikan langkahlangkah strategis untuk menjaga agar pergerakan indikator debt market Indonesia tidak terlalu berfluktuasi dan tetap mencerminkan faktor-faktor fundamentalnya. Dasar penentuan langkahlangkah ini mengacu antara lain pada hasil identifikasi dan pengukuran faktor-faktor dominan yang mempengaruhi pergerakan indikator debt market. Menjaga agar indikator debt market tidak terlalu fluktuatif dan mencerminkan faktor-faktor fundamentalnya sangatlah penting agar dapat diperoleh cost of fund pinjaman luar negeri yang wajar dan berada dalam kapasitas risiko yang terukur. Peningkatan risiko yang tidak dalam kapasitas yang terukur akan mendorong short capital flow secara cepat yang dapat mengganggu stabilitas pasar keuangan Indonesia. 
Bagian kedua dari paper ini menguraikan teori dan studi literatur. Bagian ketiga mengulas metodologi sementara hasil dan analisis diuraikan pada bagian keempat. Kesimpulan dan rekomendasi menjadi bagian penutup.

\section{TEORI}

Terdapat berbagai indikator debt market yang sering digunakan dari sudut pandang analis debt market atau investor dalam menilai risiko pinjaman luar negeri suatu negara dan perusahaan, khususnya dalam bentuk penerbit global bond baik di pasar primer maupun sekunder. Beberapa indikator yang sering digunakan antara lain yield sovereign global bond, yield corporate global bond, composite yields, spread Credit Default Swap (CDS), credit rating, credit worthiness, dan rasio keuangan.

Dalam penelitian ini difokuskan pada indikator debt market yang banyak dipakai sebagai benchmark dalam pricing penerbitan obligasi dan pemberian pinjaman bagi pemerintah dan swasta Indonesia dalam bentuk yield (imbal) yaitu yield sovereign global bond, yield corporate global bond, composite yields dan CDS.

Indikator debt market tersebut secara umum memberikan gambaran atas risiko pinjaman luar negeri, khususnya dalam bentuk penerbitan global bond baik di pasar primer maupun sekunder (portfolio investment). Indikator-indikator tersebut dapat menggambarkan dengan baik tinggi rendahnya risiko gagal bayar dengan sudut pandang yang mungkin berbeda. Yield obligasi menggambarkan risiko gagal bayar (default) dari pemerintah / negara / perusahaan penerbit utang dalam melakukan pembayaran bunga serta hutang pokok pada waktu yang telah ditetapkan berdasarkan performa dari obligasi penerbit. Dapat juga menunjukkan risiko kegagalan emiten untuk memenuhi ketentuan lain yang ditetapkan dalam kontrak obligasi. Sedangkan credit default swaps adalah bentuk paling murni dari kredit derivatif, yang menunjukkan risiko penerbit surat berharga khususnya negara berdasarkan besarnya jumlah kompensasi yang diharapkan pembeli surat berharga atas risiko yang mungkin dialami oleh penerbit. Jika terjadi suatu credit event, protection buyerakan menerima sejumlah pembayaran dari protection seller. Premi yang dibayarkan protection buyer kepada protection seller bisa dilakukan sekaligus (lumpsum) atau secara periodik.

Sekilas bila dilihat perkembangan pergerakan beberapa indikator global bond Indonesia yang direpresentasikan oleh yield obligasi global Pemerintah dan swasta Indonesia sejak tahun 2004 hingga Agustus 2009 (Grafik 2), terlihat bahwa telah terjadi lonjakan pada periode September dan Oktober 2008 hampir sekitar dua kali lipat. Lonjakan serupa namun lebih tinggi juga ditunjukkan oleh indikator CDS yang sebelumnya hanya berkisar 500-an basis points 

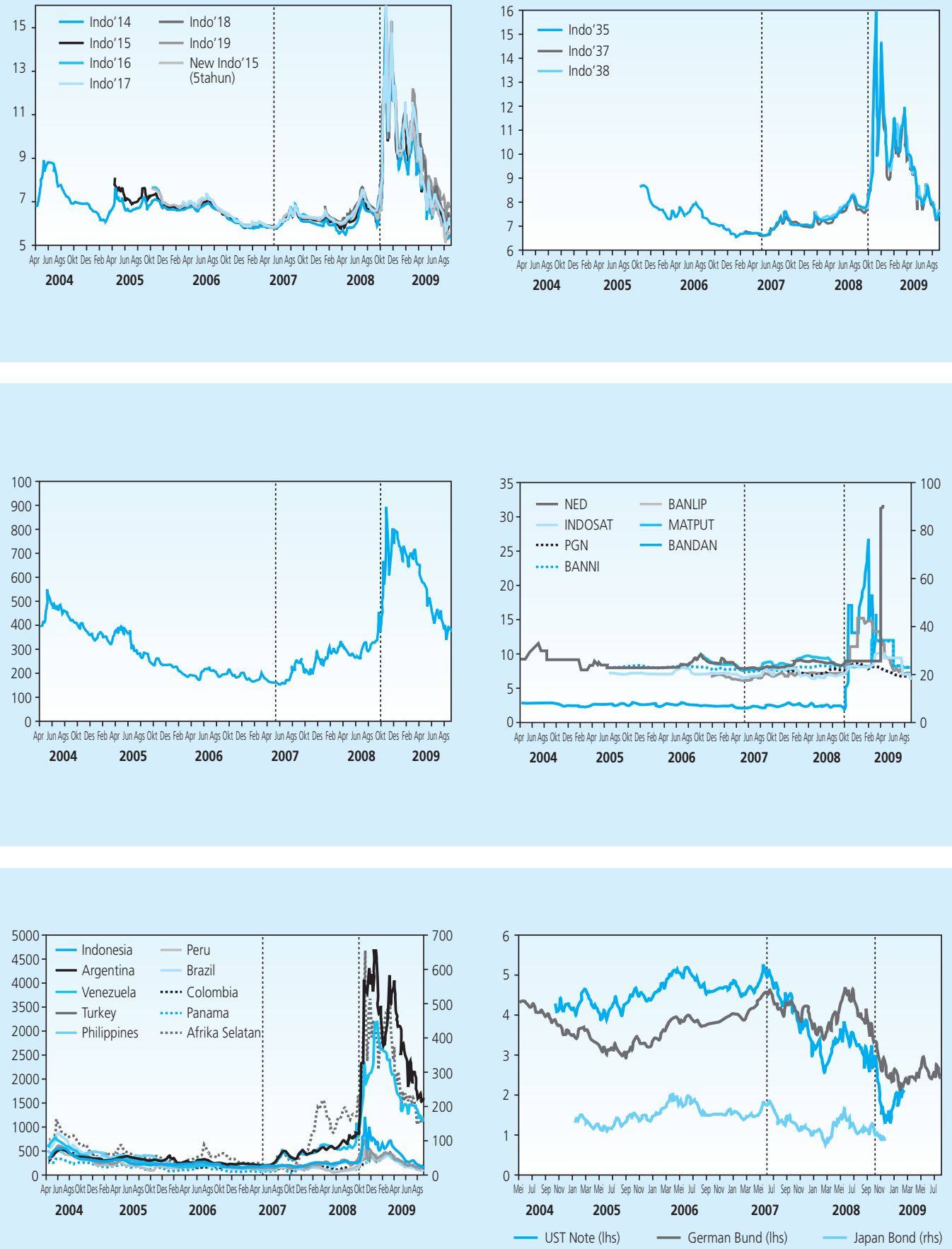

Grafik 2.

Perkembangan Pergerakan Beberapa Indikator PLN 
berubah menjadi diatas 1000an basis points. Kondisi yang lebih parah ditunjukkan oleh negara peers seperti Argentina dan Venezuela serta Turkey (mencapai diatas 4000-an basis points). Kondisi yield emerging market pada saat itu juga mengalami peningkatan sekitar dua kali lipat dari sebelumnya. Namun kondisi tersebut berangsur-angsur membaik yang ditunjukkan oleh tren penurunan angka-angka indikator tersebut. Bahkan kelihatannya pada Agustus 2009 mencapai level serupa seperti sebelum terjadinya lonjakan tersebut. Kondisi ini menunjukkan adanya perbaikan performa indikator debt market Indonesia dan peers.

Bila dibandingkan dengan pergerakan yield dari obligasi negara maju seperti G3 (US, Jepang dan Jerman) tampaknya tidak terdapat pengamatan yang khusus untuk periode sekitar September dan Oktober 2008 tersebut. Tampaknya guncangan yang terjadi di debt market global khususnya pada emerging market telah menyebabkan flight to quality sehingga yield obligasi global G3 tersebut justru menurun pada periode tersebut.

Beberapa penelitian sebelumnya menyebutkan bahwa indikator-indikator tersebut sangat baik dalam menjelaskan performa pinjaman luar negeri suatu negara atau perusahaan diantaranya adalah Min (1998). Selanjutnya, dalam penelitiannya, Min (1998) menyatakan bahwa beberapa tahun terakhir banyak negara yang mempromosikan perkembangan pasar bond masing-masing dan hasilnya pasar obligasi korporasi melambung sebesar fixed-income securities pada pasar domestik dan internasional yang secara terus-menerus menurunkan ketergantungan pada pembiayaan perbankan. Tetapi sedikit sekali yang mengetahui determinan apa saja yang mempengaruhi yield spreads dari bond yang diterbitkan oleh negara berkembang. Perubahan pada pola pembiayaan korporasi ini disebabkan oleh keperluan investasi yang substansial dalam infrastruktur dan proyek peningkatan kapital yang memerlukan pinjaman jangka panjang dengan tingkat suku bunga tetap. Hal ini yang mendorong Min melakukan penelitian mengenai determinan dari bond yield spread beberapa negara berkembang.

Lain halnya dengan Alexander \& Kaeck (2007) yang menyebutkan bahwa seiring dengan perkembangan pasar CDS yang sangat pesat menyebabkan pentingnya bagi financial analyst, traders, dan pembuat kebijakan ekonomi untuk memahami determinan dari CDS. Selain itu, CDS lebih likuid dan memiliki waktu jatuh tempo yang berbeda-beda jika dibandingkan dengan corporate bond.

Selain itu, Karlson \& Willebrand (2009) juga menyatakan bahwa semenjak terjadinya krisis kredit, banyak bank-bank besar yang mengalami gagal bayar (default). Oleh karena itu menjadi menarik untuk mengetahui faktor-faktor apa saja yang mempengaruhi resiko kredit dari institusi keuangan. CDS spreads merupakan indikator resiko kredit yang lebih baik. CDS spreads juga mengacu pada indeks CDS karena menunjukkan resiko kredit dari perusahaan individual dibandingkan group dari beberapa perusahaan. Karena CDS spreads bank-bank besar 
telah meningkat maka akan sangat penting untuk mengidentifikasikan determinan dari CDS spreads.

\subsection{Sovereign Global Bond}

Budina \& Mantchev (2000) menguji determinan dari harga Brady bond Bulgaria menggunakan data bulanan dari bulan Juli 1994 sampai dengan bulan Juli 1998. Dalam penelitian ini disimpulkan bahwa dalam jangka panjang, gross foreign reserves dan ekspor memiliki efek positif terhadap harga bond. Sedangkan real exchange rate dan depresiasi nominal exchange rate Mexico memiliki efek negatif.

Sementara itu, Nogues \& Grandes (2001) menguji determinan dari spread Argentina's floating rate bond (FRB) menggunakan data bulanan sejak bulan Januari 1994 sampai dengan Desember 1998. Mereka menyimpulkan bahwa krisis Mexico, debt service to export, pertumbuhan GDP, fiscal balance dan 30 year US Treasury yield memiliki pengaruh yang signifikan terhadap spread.

Min (1998) menganalisa determinan dari yield spreads obligasi dalam valuta US Dollar dari 11 negara berkembang dalam kurun waktu 1991 sampai dengan 1995. Hasilnya adalah bahwa perbedaan bond spreads antar negara tersebut ditentukan oleh debt to GDP, reserves to GDP, debt service to export, export dan import growth rate, inflation rate, net foreign asset, term of trade index, dan real exchange rate. Min (1998) menyimpulkan bahwa kemampuan mengakses pasar luar negeri sangat ditentukan faktor fundamental dalam negeri. Oleh karena itu disarankan agar negara-negara berkembang yang ingin mencari akses yang lebih besar terhadap pasar obligasi internasional, harus meningkatkan fundamental makroekonominya.

Namun Eichengreen \& Mody (1998) menegaskan arti penting faktor eksternal selain faktor fundamental dalam analisa sentiment pasar. Dengan menganalisa hampir 1000 data obligasi negara maju yang diterbitkan antara tahun 1991 sampai dengan 1996 ditemukan bahwa spreads yield obligasi bergantung pada issue size, credit rating issuer, debt to GDP, dan debt service to export ratio. Kesimpulan utama dari penelitian ini adalah bahwa perubahan dalam sentiment pasar, tidak hanya bergantung pada fundamental, tetapi juga faktor pasar atau faktor eksternal.

Goldman Sachs (Ades et. al. (2000)) bahkan memodelkan spreads sovereign negara berkembang dengan menambahkan faktor default history disamping beberapa faktor fundamental. Dengan menganalisa data bulanan 15 negara berkembang sejak Januari 1996 sampai dengan Mei 2000, diperoleh beberapa variabel yang memiliki efek signifikan terhadap 
spreads yaitu GDP growth rate, total external amortizations as a ratio of foreign reserves, external debt to GDP ratio, fiscal balance, export to GDP ratio, real exchange rate misalignment, international interest rate, dan default history dari negara tersebut.

Selanjutnya Rowland \& Torres (2004) dengan menggunakan teknik data panel memeriksa determinan spread dari 16 negara berkembang yang menerbitkan sovereign bond. Dengan menggunakan data tahunan dari tahun 1998 sampai dengan 2002, diperoleh bahwa GDP growth rate, external debt to GDP ratio, external debt service to GDP ratio, debt to export ratio, reserve to GDP ratio, dan export to GDP ratio memiliki pengaruh yang signifikan terhadap spread.

Kemudian Rowland (2004) melanjutkan penelitian sebelumnya dengan melakukan analisa pada 29 negara berkembang dari tahun 1998 sampai dengan akhir Juli 2003. Hasilnya adalah hanya GDP growth rate dan inflation rate yang berpengaruh signifikan terhadap spread.

Berbecaru Claudia-Floriana (2008), salah satu referensi utama dalam penelitian ini, selain mengevaluasi determinan dari sovereign bond yang diterbitkan negara-negara berkembang di Eropa, juga melakukan penelitian untuk mengetahui seberapa pentingnya kontribusi dari faktor eksternal dalam perkembangan spread dari sovereign bond Romania. Hasil dari penelitian ini menunjukkan bahwa bukan hanya faktor fundamental yang mempengaruhi perkembangan dari spread obligasi Romania tetapi juga faktor eksternal seperti risk appetite dari investor internasional. Hasil penelitian Berbecaru Claudia-Floriana tersebut mempertegas hasil penelitian sebelumnya oleh Eichengreen \& Mody (1998).

Berdasarkan data historis, pada tahun 2007 telah terjadi penurunan spread EMBIG Romania dan EMBIG composite yang diiringi dengan meningkatnya real domestik fundamental (seperti menurunnya inflasi, meningkatnya pertumbuhan GDP, menurunnya ketidakseimbangan eksternal) pada banyak negara berkembang. Menurut Berbecaru Claudia-Floriana, penurunan tersebut tidak hanya disebabkan oleh faktor domestik fundamental tetapi juga faktor eksternal. Ditunjukkan bahwa pada tahun 2002 risk appetite dari investor pada pasar internasional juga meningkat dengan cepat. Hal inilah yang mendasari Berbecaru Claudia-Floriana melakukan uji empiris menggunakan faktor fundamental dan eksternal.

Sebagai salah satu determinan spread EMBIG yang paling penting, menurut penelitian tersebut, faktor fundamental dinilai dari rezim nilai tukar, inflasi, GDP, current account, external debt, national savings, foreign exchange reserves, kebijakan fiskal dll. Dalam konteks tersebut, yang bersangkutan menggunakan peringkat sovereign untuk setiap negara dalam jangka panjang yang diterbitkan oleh lembaga rating internasional (S\&P) sebagai indikator aggregat yang menunjukkan perkembangan fundamental dari setiap negera. 


\subsection{Corporate Global Bond}

Penelitian mengenai determinan dari corporate global bond tidak sebanyak sovereign global bond. Salah satu di antaranya adalah Douglas, Huang \& Vetzal (2009). Dalam penelitiannya, ditemukan bahwa cash flow volatility secara ekonomi berpengaruh signifikan terhadap yield spread. Yasmine Meitasari \& Amelia (2007) melakukan penelitian mengenai faktor makroekonomi dan rasio-rasio keuangan terhadap return obligasi korporasi dalam negeri pada tahun 2003-2005. Hasilnya adalah suku bunga deposito, asset turnover, quick ratio, debt to equity ratio, dan return on asset tidak berpengaruh terhadap return obligasi korporasi dalam negeri.

Salah satu tujuan dan keunggulan dari rasio adalah dapat digunakan untuk membandingkan hubungan return dan resiko dari perusahaan dengan ukuran yang berbeda. Rasio juga dapat menunjukkan profil suatu perusahaan, karakteristik ekonomi, strategi bersaing dan keunikan karakteristik, keuangan dan investasi (IG. K. A. Ulupui, 2006). Menurut James C. Van Home (Sawir, 2001), analisis dan interpretasi dari macam-macam rasio dapat memberikan pandangan yang lebih baik tentang kondisi keuangan dan prestasi perusahaan dibandingkan analisis yang hanya didasarkan atas data keuangan sendiri-sendiri yang tidak berbentuk rasio. Selain itu menurut White et.al. (2002), rasio keuangan digunakan untuk membandingkan resiko dan tingkat imbal hasil dari berbagai perusahaan untuk membantu investor dan kreditor membuat keputusan investasi dan kredit yang baik.

Sementara itu, White et.al. (2002) mengelompokkan rasio keuangan menjadi 4 bagian, yaitu analisis likuiditas perusahaan, analisis Solvency dan Long Term Debt (Leverage), analisis Profitabilitas Perusahaan dan analisis Aktivitas.

1) Analisis likuiditas perusahaan

Pada umumnya perhatian pertama analis keuangan adalah likuiditas. Analisis ini mengukur kecukupan sumber kas perusahaan untuk memenuhi kewajiban yang berkaitan dengan kas dalam jangka pendek. Rasio likuiditas yang umum digunakan adalah current ratio (rasio Lancar). Current ratio merupakan ukuran yang paling umum digunakan untuk mengetahui kesanggupan memenuhi kewajiban jangka pendek karena rasio ini menunjukan seberapa jauh tuntutan dari kreditor jangka pendek dipenuhi oleh aktiva yang dipekirakan menjadi uang tunai dalam periode yang sama dengan jatuh tempo utang.

\section{Current Ratio = Current Assets/Current Liabilities}


2) Analisis Solvency dan Long Term Debt (Leverage)

Analisis ini menelaah struktur keuangan dan modal perusahaan. Struktur keuangan adalah bagaimana cara perusahaan mendanai aktivanya. Aktiva perusahaan didanai dengan utang jangka pendek, utang jangka panjang, dan modal pemegang saham, sehingga seluruh sisi kanan dari neraca memperlihatkan struktur keuangan.

Struktur modal adalah pendanaan permanen yang terdiri utang jangka panjang, saham preferen, dan modal pemegang saham. Nilai buku dari modal pemegang saham terdiri dari saham biasa, modal disetor atau surplus, modal dan akumulasi laba ditahan. Dengan persamaan :

\section{Struktur Keuangan - Hutang Lancar = Struktur Modal}

Pemilihan struktur keuangan merupakan masalah yang menyangkut komposisi pendanaan yang akan digunakan oleh perusahaan, yang pada akhirnya berarti penentuan berapa banyak hutang (leverage keuangan) yang akan digunakan oleh perusahaan untuk mendanai aktivanya.

Bila semua dana untuk membiayai aktiva perusahaan berasal dari pemilik dalam bentuk saham biasa, perusahaan tidak terikat pada kewajiban tetap untuk membayar bunga atas hutang yang diambil dalam rangka pendanaan perusahaan. Bunga adalah biaya tetap keuangan yang harus dibayar dan ditambahkan pada biaya tetap operasi tanpa mempedulikan tingkat laba perusahaan. Jadi, suatu perusahaan yang menggunakan utang akan lebih berisiko daripada perusahaan tanpa utang, karena selain mempunyai resiko bisnis, perusahaan yang menggunakan hutang mempunyai resiko keuangan. Resiko keuangan timbul karena penggunaan utang, yang menyebabkan lebih besarnya variabilitas laba bersih (net income).

Leverage keuangan adalah penggunaan hutang. Apabila hasil pengembalian atas aktiva, yang ditunjukkan oleh besarnya rentabilitas ekonomis, lebih besar daripada biaya hutang, maka leverage tersebut menguntungkan dan hasil pengembalian atas modal (rentabilitas modal sendiri) dengan penggunaan leverage ini juga akan meningkat.

Kebijakan mengenai struktur modal melibatkan trade off antara resiko dan pengembalian. Ada beberapa faktor yang mempengaruhi keputusan sehubungan dengan struktur modal. Yang pertama adalah resiko bisnis perusahaan, atau tingkat resiko yang terkandung pada aktiva perusahaan apabila ia tidak menggunakan hutang. Makin besar resiko perusahaan, makin rendah resiko utang yang optimal. Faktor kunci yang kedua adalah posisi pajak perusahaan. Alasan utama untuk menggunakan hutang adalah karena biaya bunga dapat dikurangkan dalam perhitungan pajak, sehingga meminimalkan biaya hutang yang sesungguhnya. Faktor ketiga adalah fleksibilitas keuangan, atau kemampuan untuk 
menambah modal dengan persyaratan yang masuk akal dalam kedaan yang kurang menguntungkan.

Rasio-rasio leverage yang umum digunakan antara lain, adalah rasio utang terhadap ekuitas atau DER (Debt to Equity Ratio). Rasio ini menggambarkan perbandingan hutang dan ekuitas dalam pendanaan perusahaan dan menunjukan kemampuan modal sendiri perusahaan tersebut untuk memenuhi seluruh kewajibannya.

\section{DER = Total Debt / Total Equity}

3) Analisis Profitabilitas Perusahaan

Rasio profitabilitas akan memberikan jawaban akhir tentang efektivitas manajemen perusahaan. Rasio ini memberi gambaran tentang tingkat efektivitas pengelolaan perusahaan. Salah satu rasio profitabilitas yang umum digunakan adalah margin laba bersih (Net Profit Margin atau Profit Margin on Sales). Rasio ini mengukur laba bersih setelah pajak terhadap penjualan.

\section{Net Profit Margin = Earning After Taxes ( Net Income) $/$ Sales}

4) Analisis Aktivitas

Mengevaluasi revenue dan output yang dihasilkan oleh aset perusahaan.

Eduardo Cavallo \& Patricio Valenzuela (2007) menguji determinan spread corporate bond dari negara-negara berkembang termasuk Indonesia pada tahun 1999 sampai dengan tahun 2006. Hasilnya menunjukkan spread corporate bond ditentukan oleh variabel khusus perusahaan, karakteristik bond, kondisi makroekonomi, resiko sovereign, dan faktor global. Adapun variabel khusus perusahaan yang digunakan meliputi EBIT/Asset, Equity/Capital, Debt/Asset, Size, dan volatility equity. Sedangkan kondisi makroekonomi diwakilkan oleh pertumbuhan GDP dan GDP per kapita.

\subsection{Credit Default Swap (CDS)}

Credit derivative, salah satu produk kredit terstruktur dan sekuritisasi, dituduh telah secara khusus berkontribusi kepada terjadinya krisis global (Longstaff dan Myers 2009)3. Diantara produk derivatif, yang paling populer dan banyak diminati oleh para investor adalah credit default swap (CDS). Oleh karena itu, adalah umum bagi pasar untuk membaca pergerakan CDS sebagai salah satu indikator yang menggambarkan risiko default negara.

3 Longstaff F.A and Myers B., 2009. Valuing toxic Assets: An Analysis of CDO equity, National Bureau of Economic Research. 
Alexander \& Kaeck (2007) melakukan penelitian mengenai determinan dari CDS spreads sejak Juni 2004 sampai dengan Juni 2007. Hasilnya adalah interest rate, stock returns dan implied volatility berpengaruh signifikan terhadap CDS spreads.

Keng-Yu Ho \& Yu-Jen Hsio (2004) menggunakan model Merton dan mengujinya secara empiris menggunakan data dari tahun 2001 sampai dengan 2004 untuk menganalisa determinan dari CDS spread. Hasilnya menunjukkan bahwa leverage dan implied volatility berpengaruh positif dan risk free rate berpengaruh negatif terhadap CDS spread.

Selanjutnya Karlson \& Willebrand (2009), melakukan penelitian mengenai determinan dari CDS spreads dari European financial institution. Tujuan dari penelitian ini adalah untuk menguji seberapa baik determinan teoritis mampu menjelaskan CDS spread dan apakah ada faktor lain yang mempengaruhinya. Determinan teoritis berdasarkan model Merton adalah leverage, volatility, dan risk free rate. Data yang digunakan adalah data mingguan CDS spread 30 lembaga keuangan dari Desember 2005 sampai dengan November 2008. Dengan melakukan estimasi linier data panel menggunakan variabel determinan teoritis dan variabel tambahan lainnya, diperoleh bahwa perubahan dalam historical volatility, risk free rate, equity return, implied volatility, square of risk free rate, slope of the yield, bid-ask spread, dan lagged CDS spread secara statistik signifikan dalam menjelaskan hubungannya dengan perubahan CDS spread.

Sama seperti bond spreads, CDS telah menjadi salah satu key indicator dari kualitas kredit dari korporasi, bank dan pemerintah. Biasanya Credit default swap market yang menentukan bond market sehingga kebanyakan price discovery terjadi di pasar CDS ${ }^{4}$. Studi empiris dari Deutsche Bundesbank ${ }^{5}$ menginformasikan bahwa CDS spread dan bond spread berkontribusi bagi price discovery di pasar kredit Eropa ${ }^{6}$. Pasar CDS lebih mendominasi pada saat normal namun pada saat krisis price discovery lebih ditentukan oleh bond spread. Kedua nya mengalami fluktuasi pada masa krisis.

\subsection{Credit Rating}

Credit rating merupakan indikator ketepatwaktuan pembayaran pokok dan bunga utang bond atau obligasi. Selain itu, credit rating mencerminkan skala resiko bond yang diperdagangkan. Dengan demikan credit rating menunjukkan skala keamanan bond dalam

\footnotetext{
4 Blanco, R., S. Brennan, and I.W. Marsh, 2003 "An Empirical Analysis of the Dynamic Relationship between Investment Grade Bonds and Credit Default Swaps" Working Paper, Bank of England.

5 Niko D $\square z$, 2007. Time-varying Contributions by the Corporate Bond and CDS Markets to Credit Risk Price Discovery, Deutsche Bundesbank, Discussion Paper, Series 2: Banking and Financial Studies

6 The study is based on companies listed in the iTraxx CDS index.
} 
membayar kewajiban pokok dan bunga secara tepat waktu. Semakin tinggi ratingnya, semakin menunjukkan bahwa bond tersebut terhindar dari resiko default. Sebagaimana dijelaskan diatas, credit rating untuk sebagaian peneliti seperti Berbecaru Claudia-Floriana (2008) menganggap Credit rating yang diterbitkan oleh lembaga rating yang independen, sebagai interpretasi dari kondisi fundamental suatu negara.

Dalam penelitian Berbecaru Claudia-Floriana (2008), dilakukan penelitian yang bertujuan untuk mengetahui hubungan antara spread EMBIG Romania dan beberapa negara berkembang lainnya dengan faktor fundamental yang diwakilkan oleh credit rating serta faktor risk appetite investor internasional yang diwakilkan oleh volatilitas indeks VIX. Hasilnya adalah terdapat hubungan jangka panjang antara spread EMBIG, credit rating dan indeks VIX.

Di Indonesia terdapat dua lembaga rating, yaitu PEFINDO (Pemeringkat Efek Indonesia) dan Kasnic Credit Rating Indonesia. Sedangkan dalam lingkup internasional terdapat cukup banyak lembaga rating, di antaranya adalah Moody's, S\&P, dan Fitch. Lembaga rating tersebut membantu investor dalam memberikan informasi investasi mengenai kemampuan ekonomi dan finansial penerbit (issuer) bond. Rating bond yang dilakukan oleh lembaga rating memberikan gambaran tentang kredibilitas (credit worthiness) dan mempengaruhi penjualan bond tersebut (Fabozzi, 2000). Posisi credit rating biasanya berubah apabila terjadi perubahan yang cukup signifikan pada faktor-faktor determinannya, misalnya perbaikan kondisi ekonomi, sosial dan politik yang didukung oleh berbagai paket kebijakan pemerintah yang lebih baik, atau sebaliknya, memburuknya perekonomian suatu negara. Namun kondisi rating dapat pula dipengaruhi oleh faktor-faktor global. Perubahan credit rating tidaklah secepat perubahan yield obligasi ataupun CDS.

\section{METODOLOGI}

\subsection{Spesifikasi Model Empiris}

Mengacu pada penelitian-penelitian sebelumnya, berikut spesifikasi model yang digunakan pada penelitian ini dalam menentukan faktor-faktor yang mempengaruhi masing-masing indikator :

\section{1) Indikator Yield Sovereign Global Bond}

Yield sovereign global bond dikelompokkan menjadi dua, yaitu yield individual sovereign global bond dan yield composite sovereign global bond. Individual sovereign global bond merupakan obligasi global atau luar negeri yang diterbitkan oleh pemerintah suatu negara. Obligasi Pemerintah INDO14 dipilih sebagai wakil dari obligasi-obligasi yang diterbitkan 
pemerintah Indonesia karena ketersediaan data yang cukup panjang. Sedangkan composite sovereign global bond adalah komposit dari obligasi global atau foreign emerging market bond index (EMBI) yang diproduksi oleh JP. Morgan.

Pemilihan model dibawah ini, sesuai dengan penelitian-penelitian sebelumnya yang memasukkan beberapa variable makroekonomi yang menentukan pergerakan dari spread yield obligasi seperti penelitian dari Budina \& Mantchev (2000), Nogues \& Grandes (2001), Min (1998), Goldman Sachs (Ades et. al. (2000), Rowland \& Torres (2004) dan Rowland (2004). Namun demikian, pengembangan model dilakukan sesuai dengan penelitian dari Eichengreen \& Mody (1998) yang menyimpulkan bahwa bukan hanya fundamental yang menentukan pandangan pasar tetapi juga faktor eksternal. Oleh karena itu, ditambahkan variabel news dalam bentuk dummy sebagai faktor yang mempengruhi pergerakan yield sovereign global bond Indonesia dan Peers dan composite yield.

Secara umum, model empiris yang digunakan terbagi menjadi dua, yakni model penentu yield obligasi global dengan vektor variabel penentu yang berasal dari domestik dan eksternal. Berpedoman pada model yang dikembangkan oleh Berbecaru Claudia-Floriana (2008), untuk menguji apakah faktor-faktor eksternal juga mempengaruhi individual sovereign global bond Indonesia dengan model empiris berikut:

Indo $14=f(G D P, F B / G D P, I N F, F R, V I X$, Fut. RATE, Volat. rate)

Dengan menggunakan data yang lebih luas, varian model ini juga dipergunakan untuk menganalisis determinan yield sovereign global bond beberapa negara yakni Indonesia dan negara-negara peers-nya. Spesifikasi varian model ini adalah:

Yield $=f(G D P, F B / G D P, I N F, F R, T E X T D / F R, D 1, V I X)$

Untuk yield komposit, model empiris diaplikasikan pada data Indonesia dan negara-negara peers-nya sebagai berikut:

$$
E M B I=f(G D P, F B / G D P, R E E R, D S R, D 1)
$$

\section{2) Indikator Yield Corporate Global Bond}

Sebagaimana yield global sovereign bond, yield corporate global bond dikelompokkan menjadi dua, yaitu yield individual corporate global bond dan yield composite corporate global bond. Individual corporate global bond merupakan obligasi global atau luar negeri yang diterbitkan oleh suatu perusahaan. Sedangkan composite corporate global bond (CEMBI) merupakan komposit dari obligasi global atau luar negeri yang diterbitkan oleh beberapa perusahaan di beberapa negara berkembang. 
Model yang dibentuk dalam penelitian ini sesuai dengan penelitian Eduardo Cavallo \& Patricio Valenzuela (2007) dengan mengkombinasikan faktor-faktor mikro dan makro sebagai determinan dari pergerakan spread corporate bond. Penelitian lain yang merupakan pendukung kajian ini adalah Douglas, Huang \& Vetzal (2009), Yasmine M Eduardo Cavallo \& Patricio Valenzuela (2007), Itasari \& Amelia (2007) yang selain faktor makro juga memasukkan rasio keungan perusahaan (unsur mikro). Menurut IG. K. A. Ulupui, 2006 dan James C. Van Home (Sawir, 2001), rasio juga dapat menunjukkan profil suatu perusahaan, karakteristik ekonomi, strategi bersaing dan keunikan karakteristik, keuangan dan investasi analisis. White et.al. (2002) juga melakukan penekanan pada faktor penting rasio keuangan untuk membandingkan resiko dan tingkat imbal hasil dari berbagai perusahaan untuk membantu investor dan kreditor membuat keputusan investasi dan kredit yang baik. Spesifikasi persamaannya adalah:

\section{Yield corporate global bond $=f(C R, D E R, N P M, R O E, I N F)$}

\section{3) Indikator Yield Credit Default Swap (CDS)}

Penelitian ini mengembangkan model Karlson \& Willebrand (2009) yang merupakan pengembangan dari model Merton. Merton menggunakan variable leverage, volatility, dan risk free rate untuk menjelaskan pergerakan spread CDS sedangkan Karlson \& Willebrand menambahkan variable historical volatility, risk free rate, equity return, implied volatility, square of risk free rate, slope of the yield, bid-ask spread, dan lagged CDS spread yang secara statistik signifikan dalam menjelaskan hubungannya dengan perubahan CDS spreads.

Penelitian lain yang mengemukakan variabel CDS yang juga sebagai referensi dalam penelitian ini adalah Alexander \& Kaeck (2007) dan Keng-Yu Ho \& Yu-Jen Hsio (2004) yang menggunakan model Merton dan menghasilkan bahwa leverage dan implied volatility berpengaruh positif dan risk free rate berpengaruh negatif terhadap CDS spread. Model emprisinya adalah:

Yield CDS = f( UST, VSTOXX, CDS Bid ask, CDS, GDP)

\subsection{Teknik Estimasi dan Data}

Teknis estimasi regresi data panel digunakan untuk model yield sovereign peers, yield composite dan yield CDS peers. Untuk mengestimasi model regresi dengan data panel dapat digunakan 3 pendekatan yaitu OLS (common effect), variabel dummy (fixed effect), dan random effect. 
Data yang digunakan pada penelitian ini terutama data Indonesia (INDO). Namun untuk mempertajam analisa, dilakukan perbandingan dengan dengan beberapa negara peers (dalam hal ini memiliki credit rating dalam range yang sama) yaitu Brazil (BRA), Colombia (COL), Panama (PAN), Peru (PERU), Phillipina (PHIL), Turkey (TURK), dan South Africa (SA). Untuk indikator corporate global bond, sampel yang digunakan adalah 10 korporasi yang terdiri dari 6 perusahaan dan 4 bank, dimana korporasi tersebut adalah korporasi yang menerbitkan foreign bond atau global bond yaitu PT. Indosat Tbk (INDOSAT), Medco Energy International (MEDCO), PT. Excelcomindo Tbk (EXCEL), PT. Matahari putra Prima (MATPUT), Sanyo Elektronik Indonesia (SANYO), Perusahaan Gas Negara (PGN), Bank Negara Indonesia (BNI), Bank Danamon (BANDAN), Bank Niaga (BANNI), Bank Lippo (BANLIP). Untuk model data panel, digunakan data tahunan. Sedangkan untuk model data time series, digunakan data bulanan. Sumber data yang digunakan adalah Bloomberg, Moody's, IFS, dan Bank Indonesia.

\section{HASIL DAN ANALISIS}

\subsection{Yield Individual Sovereign Global Bond}

Dengan menggunakan data Indonesia, hasil estimasi atas pengaruh faktor fundamental dan faktor eksternal terhadap yield obligasi sovereign pemerintah Indonesia (INDO14) diberikan di bawah ini. Model empiris ini mengacu pada Berbecaru Claudia \& Floriana (2008):

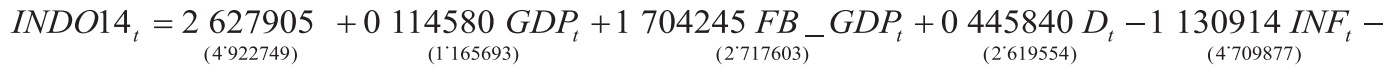

$$
\begin{aligned}
& 0736703 \mathrm{FR}_{t}{ }^{*}+0270265 \mathrm{VIX}_{t}{ }^{*}-0280411 \mathrm{FUT}_{-} \mathrm{RATE}_{t}-3603485 \mathrm{VOL}_{-} \mathrm{RATE}_{t} \\
& \text { (0.262587) (0.047631) } \\
& R^{2}=0.555854, \quad * \text { ) Sig. } \alpha=10 \%
\end{aligned}
$$

Hasil estimasi ini menunjukkan bawah faktor fundamental yang paling signifikan mempengaruhi yield sovereign global bond Indonesia adalah foreign reserves (FR) sementara faktor eksternalnya adalah indeks VIX.

Peran foreign reserve sangat signifikan dalam menentukan besarnya asuransi yang diperlukan oleh investor ketika membeli surat berharga suatu negara. Pengujian empiris ini menunjukkan bahwa untuk peningkatan foreign reserves sebesar $1 \%$ akan menyebabkan penurunan yield sovereign global bond Indonesia sebesar $0.737 \%$. Sementara itu, indeks VIX sebagai salah satu pengukuran utama dari ekspektasi pasar volatilitas jangka pendek (30 hari), yang biasanya menjadi bahan pertimbangan banyak orang untuk menjadi barometer dari sentimen investor dan volatilitas pasar global, juga sangat signifikan mempengaruhi besarnya kompensasi yang diperlukan oleh investor ketika memegang surat utang Indonesia. Sebagaimana 
dikemukakan sebelumnya, VIX cenderung turun saat sentimen pasar meningkat. Oleh karena itu, VIX dapat dipertimbangkan sebagai suatu proksi bagi investor untuk menghindari resiko dan dapat menjelaskan pergerakan spread dari emerging market bond (K. Hartelius, K. Kashiwase, L.E. Kodres 2008). Namun, berdasarkan penelitian ini, pengaruh foreign reserves lebih besar dibandingkan dengan pengaruh indeks VIX.

Untuk data kawasan meliputi Indonesia dan peer-nya, estimasi model empiris dilakukan dengan menggunakan teknik estimasi data panel common effect, dan hasilnya diberikah sebagai berikut :

$$
\begin{aligned}
& Y I E L D_{i t}=-31.03194+1.247196 . G D P_{i t}+1.303275 . F B \_G D P_{i t}+7.425715 . D 1_{i t}{ }^{*}-0.659693 . I N F_{i t}- \\
& \begin{array}{lllll}
(17.37858) & (3.148757) & (2.313377) & (2.4284) & (0.669138)
\end{array} \\
& \underset{(0.038218)}{0.096408 . F R_{i t}{ }^{* *}}+\underset{(1.226606)}{0.181007 . T E X T D_{-} F R_{i t}}+\underset{(0.242820)}{0.675921 . V I X_{i t}}{ }^{* *} \\
& \left.\left.R^{2}=0.556758, \quad \quad *\right) \text { Sig. } \alpha=1 \%, \quad * *\right) \text { Sig. } \alpha=5 \%
\end{aligned}
$$

Model ini menunjukkan bahwa yield sovereign global bond secara signifikan dipengaruhi oleh foreign reserves (FR) dan indeks VIX, dan dummy issue (D1). Berdasarkan hasil uji empiris di atas, persentase perubahan foreign reserves mempengaruhi secara negatif terhadap yield sovereign global bond yang berarti peningkatan cadangan devisa akan menurunkan yield sovereign global bond negara-negara tersebut. Hal ini juga sesuai dengan penelitian yang dilakukan Budina \& Mantchev (2000), bahwa foreign reserves dipertimbangkan menjadi faktor penting pertama saat membahas peluang terjadinya krisis. Karenanya semakin rendah foreign reserves suatu negara maka semakin rendah peringkat resiko negara tersebut, artinya semakin besar peluang terjadinya default.

Indeks VIX, berpengaruh positif terhadapyield obligasi soverign global, dimana setiap peningkatan $1 \%$ indkes VIX akan mendorong peningkatan yield sebesar 0,75\%. Siginifikansi indeks VIX ini sejalan dengan pernyataan K. Hartelius, K. Kashiwase, L.E. Kodres (2008) bahwa indeks VIX dapat dipertimbangkan sebagai suatu proksi bagi investor untuk menghindari resiko. Yield sovereign gobal bond mencerminkan default risk dari suatu negara dan tingkat unwillingness investor untuk membeli obligasi negara tersebut. Jadi risk appetite dari investor yang ditentukan oleh kondisi keuangan investor, resiko likuiditas dalam debt market, sangat mempengaruhi pergerakan yield sovereign global bond.

Hal yang menarik dari hasil ini adalah variabel dummy issue signifikan mempengaruhi yield, artinya issue khususnya berita negatif secara signifikan meningkatkan yield. Oleh karena itu, tampaknya tidaklah tepat apabila pengambil kebijakan meremehkan berbagai isu yang beredar di pasar terutama apabila isu yang berkembang tersebut bersifat negatif. Untuk 
merespon hal ini, pemangku kebijakan perlu mengolah berbagai isu yang berkembang di pasar serta mengupayakan berbagai usaha untuk meminimalisir isu negatif mengenai Indonesia di pasar internasional. Beberapa cara yang dapat ditempuh antara lain memberi penjelasan, mengarahkan dan secara konsisten menjaga kredibilitas informasi yang disampaikan.

\subsection{Yield Composite Sovereign Global Bond}

Dan untuk melihat hubungan antara yield composite sovereign global bond dengan faktor fundamental beberapa negara termasuk Indonesia, dengan menggunakan estimasi data panel, maka berdasarkan uji pemilihan model, model yang akan dianalisa adalah model dengan menggunakan metode common effect. Hasil estimasinya sebagai berikut:

$$
\begin{aligned}
& E M B I_{i t}=\underset{(5.0236)}{2.6163}+\underset{(0.5841)}{0.1249 . G D P_{i t}}+\underset{(0.4711)}{0.2226 F B} G D P_{i t}-\underset{(1.174)}{1.3364 . D 1_{i t}}-\underset{(0.0916)}{0.2003 . R E E R_{i t}^{* *}}+ \\
& 0.2890 . D S R_{i t}^{*}
\end{aligned}
$$

$R^{2}=0.4188, \quad$ *) Sig. $\left.\alpha=1 \%, \quad * *\right)$ Sig. $\alpha=5 \%$

Hasil estimasi ini menunjukkan bahwa untuk data Indonesia dan negara peers-nya, variabel yang mempengaruhi yield komposit regi $\square$ ini hanya nilai tukar riile efektif (REER) dan resiko default (DSR), sementara variabel fundamental yakni GDP dan issu pasar, justru tidak memberikan berpengaruh secara signifikan.

REER atau nilai tukar riil efektif yang merupakan nilai tukar tertimbang suatu mata uang terhadap sekaranjang mata uang (basket currency) yang telah disesuaikan dengan inflasi pada tahun tertentu. Umumnya, bobot timbangan nilai tukar masing-masing mata uang ini menggunakan nilai perdagangan negara-negara tersebut. Karenanya REER lebih tepat digunakan sebagai indeks untuk mengukur tingkat daya saing ekspor suatu negara. Berdasarkan hasil estimasi model, apresiasi REER sebesar $1 \%$ akan menyebabkan penurunan indeks yield komposit sebesar $0.2 \%$.

Selain REER, variabel DSR juga signifikan mempengaruhi yield composite sovereign global bond secara positif. Rasio ini menunjukkan berapa banyak jumlah pendapatan yang dibutuhkan dalam setahun untuk membayar total hutang tahunan, sehingga semakin besar DSR maka resiko default akan semakin besar. Hasil estimasi ini menunjukkan bahwa peningkatan resiko default akibat peningkatan DSR sebesar 1\% akan mendorong peningkatan yield komposit EMBI sebesar $0.289 \%$. 


\subsection{Yield corporate global bond}

Dalam menganalisa kasus yield corporate global bond, berdasarkan jurnal Eduardo Cavallo \& Patricio Valenzuela (2007) dan dengan menggunakan estimasi data panel dan uji pemilihan model, diperoleh hasil estimasi menggunakan metode common effect sebagai berikut:

$$
\begin{aligned}
& \text { Yield_Corp } p_{i t}=\underset{(0.7748)}{0.38688}+\underset{(0.003189)}{0.0142 . C R_{i t}}{ }^{*}-\underset{(0.001782)}{0.00244 . D E R_{i t}}+\underset{(0.01749)}{0.1519 . N P M_{i t}}{ }^{*}-\underset{(0.016617)}{0.03664 . R O E_{i t}}{ }^{* *}+ \\
& 0.7029 . I N F_{i t}^{*} \\
& (0.10361)
\end{aligned}
$$$$
\left.R^{2}=0.6588, \quad \quad * \text { ) Sig. } \alpha=1 \%, \quad * *\right) \text { Sig. } \alpha=5 \%
$$

Dari hasil estimasi dapat dilihat bahwa hampir seluruh variabel kecuali debt equity ratio (DER) secara signifikan mempengaruhi yield individual corporate global bond untuk korporasi di Indonesia.

Return on Equity (ROE) signifikan mempengaruhi yield korporasi Indonesia. Rasio ini menunjukkan kemampuan modal sendiri untuk menghasilkan keuntungan. Jadi ketika ROE suatu perusahaan meningkat maka yield korporasi Indonesia akan menurun. Secara empiris untuk pasar obligasi perusahaan di Indonesia, peningkatan ROE 1\% akan menekan yield obligasi perusahaan sebesar $0.03 \%$.

Spesifikasi model empiris di atas hanya memasukkan satu variabel makro yaitu inflasi. Hal ini dikarenakan inflasi merupakan indikator harga yang akan mempengaruhi produksi dan profit dari korporasi. Berdasarkan hasil estimasi di atas, ternyata inflasi sangat mempengaruhi yield korporasi di Indonesia. Hal ini dapat dilihat dari besarnya koefisien inflasi. Jika inflasi meningkat sebesar 1\% maka yield korporasi Indonesia akan meningkat sebesar 0.702982\%.

Pada sisi lain, hasil estimasi empiris di atas menunjukkan adanya anomali dimana pengaruh current ratio (CR) dan net profit margin (NPM), memberikan pengaruh positif terhadap yield obligasi korporasi, dan ini berkebalikan dengan teori. Current ratio menunjukkan perbandingan aset lancar perusahaan terhadap utang lancar, sehingga magnitude $C R$ yang lebih besar menunjukkan fundamental perusahaan yang semakin baik. Konsekuensinya adalah, yield obligasi yang diterbitkan perusahaan yang sehat tersebut, tidak perlu besar atau cenderung lebih rendah dibandingkan perusahaan yang fundamentalnya lebih lemah. Ini berarti CR seharusnya berpengaruh negatif terhadap yield. Logika yang sama juga berlaku untuk keuntungan perusahaan (NPM).

Berdasarkan penelitian Ulupui (2006), dugaan mengenai anomali ini adalah karena pasca krisis ekonomi, investor mulai memperhatikan manajemen kas, piutang, dan persediaan perusahaan sebelum mengambil keputusan untuk berinvestasi. Dengan demikian, meskipun 
aset lancar jauh melebihi kewajiban lancar atau meskipun tingkat keuntungan semakin besar namun kondisi-kondisi tersebut masih tetap memberikan kekhawatiran bagi investor akan kemampuan perusahaan dalam mengelola kas dan piutang.

Pada dasarnya, current ratio menunjukkan tingkat keamanan (margin of safety) atau kemampuan perusahaan untuk membayar hutang-hutang tersebut. Tetapi suatu perusahaan dengan current ratio yang tinggi belum tentu menjamin akan dapat dibayarnya hutang perusahaan yang sudah jatuh tempo karena terdapat kemungkinan bahwa besarnya persediaan yang menjadi faktor penyebab menggunungnya aset. Proporsi atau distribusi dari aktiva lancar yang tidak menguntungkan, karena jumlah persediaan yang relatif tinggi dibandingkan taksiran tingkat penjualan yang akan datang tersebut menyebabkan tingkat perputaran persediaan rendah dan menunjukkan adanya over investment dalam persediaan tersebut. Ditambah lagi kondisi saldo piutang yang besar namun sulit untuk ditagih. Oleh karena itu, rendahnya kemampuan perusahaan untuk menghasilkan pendapatan bagi perusahaan akan meningkatkan risiko perusahaan tersebut mengalami default. Oleh karena itu, yield masih tetap meningkat.

Disamping itu, meskipun pada umumnya suatu current ratio yang rendah lebih banyak mengandung risiko dari pada suatu current ratio yang tinggi, tetapi kadang-kadang suatu current ratio yang rendah malahan menunjukkan pimpinan perusahaan menggunakan aktiva lancar dengan sangat efektif. Yaitu bila saldo disesuaikan dengan kebutuhan minimum saja dan perputaran piutang dari persediaan ditingkatkan sampai pada tingkat maksimum. Jumlah kas yang diperlukan tergantung dari besarnya perusahaan dan terutama dari jumlah uang yang diperlukan untuk membayar utang lancar, berbagai biaya rutin dan pengeluaran darurat (Tunggal, 1995: 157).

Dalam hal NPM, secara umum NPM merupakan salah satu rasio profitabilitas yang akan memberikan jawaban akhir tentang efektivitas manajemen perusahaan. Rasio ini memberi gambaran tentang tingkat efektivitas pengelolaan perusahaan. Semakin besar rasio NPM maka net profit-nya juga akan semakin besar sehingga dapat dikatakan tingkat efektivitas pengelolaan perusahaan semakin baik. Hal ini akan berdampak pada resiko default akan semakin kecil. Tetapi jika net profit yang besar tersebut lebih banyak digunakan untuk membayar pajak atau biaya-biaya lainnya yang jumlahnya lebih besar dari pembayaran utang maka dampaknya terhadap resiko default akan cenderung membesar.

\subsection{Yield CDS}

Berdasarkan model yang digunakan dalam penelitian Alexander \& Kaeck (2007) untuk menganalisa hubungan antara yield CDS Indonesia dengan faktor determinansinya, hasil estimasi menggunakan metode OLS adalah sebagai berikut: 


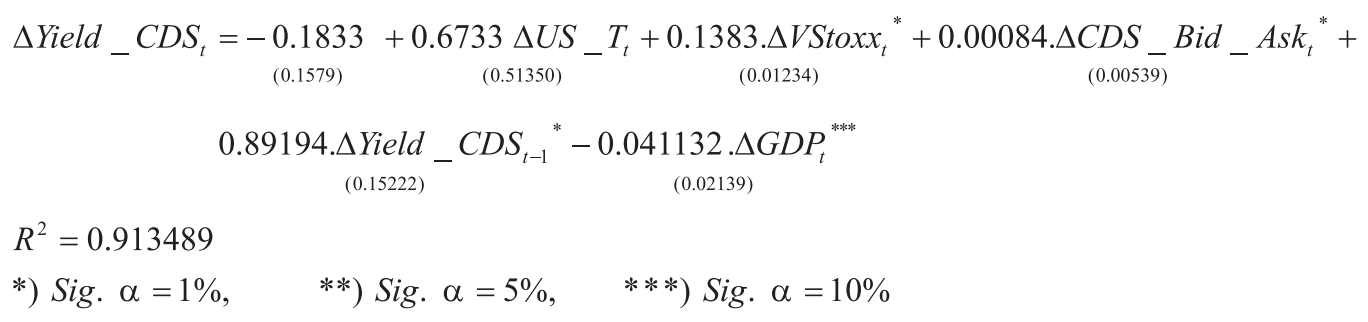

Berdasarkan hasil estimasi di atas, terdapat tiga variabel yang signifikan mempengaruhi yield CDS Indonesia. Pertama adalah implied volatility yang mencerminkan pandangan pasar terhadap Indonesia yang dicerminkan oleh perubahan VStoxx index. Jika terjadi peningkatan index sebesar 1\%, akan meningkatkan probabilitas terjadinya default (yield) sebesar $0.138352 \%$. Selain itu yield CDS juga dipengaruhi secara positif oleh nilai yield CDS sebelumnya sebesar $0.891946 \%$.

Selain faktor eksternal, terdapat faktor fundamental makroekonomi yang mempengaruhi yield CDS Indonesia secara negatif, yaitu pertumbuhan GDP riil. Hal ini menunjukkan bahwa tingkat risiko negara khususnya Indonesia sangat dipengaruhi oleh kondisi pertumbuhan ekonomi Indonesia, yang dicerminkan oleh GDP riil Indonesia. Hal ini sesuai dengan teori yang menyatakan bahwa semakin baik kondisi ekonomi suatu negara semakin kecil risiko default negara tersebut dipandang oleh investor. Namun dari ketiga variabel yang signifikan mempengaruhi pergerakan yield CDS Indonesia tersebut, yang memiliki pengaruh paling besar adalah yield CDS sebelumnya. Oleh karenanya, upaya yang terus-menerus untuk menjaga pergerakan CDS pada level yang dianggap aman sangat penting dilakukan.

Untuk menganalisa hubungan antara yield CDS Indonesia dan peers dengan faktor determinansinya digunakan model yang sama dengan sebelumnya, hanya saja metode yang digunakan berbeda yaitu estimasi data panel. Maka berdasarkan uji pemilihan model, model yang akan dianalisa adalah model menggunakan metode fixed effect :

$$
\begin{aligned}
& \Delta \text { Yield_CDS } S_{i t}=\underset{(0.311896)}{-0.8925}+\underset{(0.57119)}{0.5261 . \Delta U S} T_{i t}+\underset{(0.063044)}{0.2182 . \Delta V S t o x x_{i t}}{ }^{*}+\underset{(0.00353 \overline{8})}{0.00084 . \Delta R} \text { FISE }{ }_{i t}{ }^{*}
\end{aligned}
$$

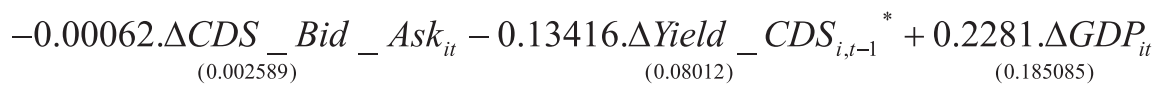

$R^{2}=0.399709, \quad$ *) Sig. $\alpha=1 \%$, 
dengan fixed effect (cross) masing-masing negara sebagai berikut :

\begin{tabular}{|l|r|}
\hline _PHIL_C & -0.644844 \\
_INDO-C & 0.138755 \\
_BRA-C & -1.266955 \\
_COL-C & 2.481957 \\
_PERU-C & -0.680520 \\
_TURK-C & 0.225518 \\
_PAN-C & -0.553362 \\
_SA-C & 0.299449 \\
\hline
\end{tabular}

Sama halnya dengan yield CDS Indonesia, perubahan VStoxx index yang mencerminkan tingkat risiko negara berlaku juga untuk peers. Meningkatnya volatilitas akan meningkatkan probabilitas terjadinya default. Dan ketika probabilitas default meningkat maka biaya asuransi untuk default tersebut yang digambarkan oleh yield CDS, akan meningkat juga. Oleh karena itu, yield CDS akan meningkat ketika volatilitas meningkat. Jadi dapat disimpulkan bahwa yield CDS sangat ditentukan oleh volatilitas yang diproksikan oleh indeks VStoxx.

\section{KESIMPULAN}

Penelitian ini menganalisis pasar hutang di Indonesia dengan fokus pada 2 indikator yakni yield obligasi (individual maupun komposit) dan yield CDS (Credit Default Swap). Penelitian ini memberikan beberapa kesimpulan, pertama, secara empiris penelitian ini menunjukkan bahwa dalam pasar hutang di Indonesia, tingkat inflasi, cadangan luar negeri (yang mencerminkan kondisi likuiditas) dan indeks VIX (yang mencerminkan tingkat sentimen pasar), berpengaruh terhadap pergerakan yield obligasi global pemerintah Indonesia. Kesimpulan ini sejalan dengan kondisi pasar hutang individual sejumlah negara peers Indonesia. Untuk yield komposit obligasi pemerintah (composite sovereign global bond), faktor yang berpengaruh adalah nilai tukar efektif riil atau REER dan debt service ratio (DSR). Kedua, pergerakan yield untuk obligasi korporasi, dipengaruhi oleh kondisi fundamental perusahaan yakni current ratio, net profit margin, return on equity dan juga oleh inflasi. Untuk indikator yield CDS, yield CDS Indonesia secara signifikan dipengaruhi oleh indeks VSTOXX, yield CDS sebelumnya dan pertumbuhan GDP

Hasil penelitian ini memberikan beberapa implikasi. Bagi otoritas moneter, paling tidak terdapat 2 hal, pertama mengingat bahwa inflasi secara signifikan mempengaruhi pergerakan yield global government bond Indonesia. Oleh karena itu, Bank Indonesia sebagai otoritas yang bertanggungjawab dalam menjaga tingkat inflasi perlu memiliki komitmen yang kuat 
untuk secara kontinyu meningkatkan transparansi dan kecepatan informasi atas kebijakan moneter yang diambil sesuai dengan international best practices dalam inflation targeting framework. Disamping itu juga perlu melakukan optimasi penggunakan media dan perluasan akses bagi pasar dalam penyampaian infomasi dan data terkait kebijakan moneter. Kedua, Bank Indonesia perlu terus melakukan upaya dalam mengamankan jalur supply likuiditas valas agar tidak menimbulkan tekanan pada nilai tukar dan agar nilai tukar benar-benar mencerminkan faktor fundamentalnya, baik dalam bentuk supply demand valas untuk kegiatan ekspor-impor, FDI, pinjaman luar negeri maupun portfolio investment. 


\section{DAFTAR PUSTAKA}

Ades, Alberto, Frederico Kaune, Paulo Leme, Rumi Masih, and Daniel Tenengauzer, 2000, "Introducing GS-ESS: A New Framework for Assessing Fair Value in Emerging Markets HardCurrency Debt", Global Economic Paper No. 45, Goldman Sachs, New York.

Alexander, Carol., and Kaeck, Andreas., 2007, "Regime Dependent Determinants of Credit

Default Swap Spreads", ICMA Centre, University of Reading, UK.

Blanco, R., S. Brennan, and I.W. Marsh, 2003, "An Empirical Analysis of the Dynamic Relationship

between Investment Grade Bonds and Credit Default Swaps", Working Paper, Bank of England.

Budina, Nina, and Tzvetan Mantchev, 2000, "Determinants of Bulgarian Brady Bond Prices: An Empirical Assessment", Policy Research Working Paper No. WPS 2277, The World Bank, Washington D.C.

Cavallo, E., and Valenzuela, P., 2007, "The Determinants of Corporate Risk in Emerging Markets : An Option-Adjusted Spread Analysis", IMF Working Paper No. WP/07/228.

Claudia-Floriana, Berbecaru, 2008, "Determinants of Spreads of Romanian Sovereign Bonds:

An Application on The EMBIG Spreads", dissertation paper of The Academy of Economic Studies Bucharest.

Douglas, Alan.V.S., Huang, Alan.G, and Vetzal. Kenneth.R., 2009, "Cash Flow Volatility and

Corporate Bond Yield Spreads", School of Accounting and Finance, University of Waterloo, Kanada.

Edwards, Sebastian, 1983, "LDC's Foreign Borrowing and Default Risk: An Empirical Investigation

1976-1980", Working Paper No. 298, Department of Economics, University of California, Los Angeles.

Eichengreen, Barry, and Ashoka Mody, 1998, "What Explains Changing Spreads on Emerging-

Market Debt? Fundamentals or Market Sentiment?", NBER Working Paper No 6408 (Cambridge, MA : National Bureau of Economic Research).

Howeling, P. and T. Vorst, 2001, "An Empirical Comparison of Default Swap Pricing Models", mimeo, Rabobank.

IMF and World Bank, 2003, "Guideline for Public Debt Management," "IMF Publication on Public Debt.

Karlson, E. and Willebrand, N., 2009, "Examining The Determinants of Credit Default Swap Spreads", A Study of European Financial Institutions, Stockholm University. 
Longstaff F.A and Myers B., 2009, "Valuing toxic Assets: An Analysis of CDO equity", National Bureau of Economic Research.

Meitasari, Yasmine, dan Emelia, 2007, "Analisa Pengaruh Suku Bunga dan Rasio-Rasio Keuangan terhadap Return Obligasi Korporasi (Studi Kasus pada Obligasi yang Memiliki Peringkat Investment Grade yang Terdaftar di Bursa Efek Surabaya Periode 2003-2005)", Skripsi Program Studi Manajemen Fakultas Ekonomi Universitas Kristen Petra, Surabaya.

Merton, R., 1974, "On the Pricing of Corporate Debt: The Risk Structure of Interest Rates," "Journal of Finance No. 29 Vol. 2, pp. 449-70.

Niko D $\square z$, 2007, "Time-varying Contributions by the Corporate Bond and CDS Markets to Credit Risk Price Discovery", Deutsche Bundesbank, Discussion Paper, Series 2 : Banking and Financial Studies.

Nogués, Julio, and Martద Grandes, 2001, "Country Risk: Economic Policy, Contagion Effect or Political Noise?", Journal of Applied Economics, Vol. 4, No. 1, May, pp.125-162.

Rojas, Alvaro, and Felipe Jaque, 2003, "Determinants of the Chilean Sovereign Spread : Is It Purely Fundamentals?", Documentos de Trabajo, Banco Central de Chile.

Rowland, Peter, 2004, "The Colombian Sovereign Spread and its Determinants", Borradores de Economla, Banco de la Rep $\square$ lica, Bogotá.

2004, "Determinants of Spread, Credit Ratings and Creditworthiness for Emerging Market Sovereign Debt : A Follow-Up Study Using Pooled Data Analysis", "Borradores de Economa, Banco de la Rep $\square$ lica, Bogotá.

, and Torres, Jose.L., 2004, "Determinant of Spread and Creditworthiness for Emerging Market Sovereign Debt : A Panel Data Study", Borradores de Econom国, Banco de la Rep $\square$ lica, Bogotá.

Sawir, A., 2001, Analisis Kinerja Keuangan dan Perencanaan Keuangan Perusahaan. PT. Gramedia Putaka Utama, Jakarta.

Tunggal, AW., 1995, Dasar-dasar Analisa Laporan Keuangan. Rineka Utama, Jakarta.

Ulupui, I. G. K. A, 2006, "Analisis Pengaruh Rasio Likuiditas, Leverage, Aktivitas, dan Profitabilitas terhadap Return saham (Studi pada Perusahaan Makanan dan Minuman dengan Kategori Industri Barang Konsumsi di Bursa Efek Jakarta)" ," Jurnal Akuntansi dan Bisnis. Vol. 2. No. 1, Januari: 88 - 102 .

White G.I., Ashwinpaul C. Sondhi dan Dov Fried, 2003, "The Analysis and Use of Financial Statements". USA : John Wiley. pg. 119-135. 
halaman ini sengaja dikosongkan 